\title{
SUSCEPTIBILITY OF SOME BEAN VARIETIES; PHASEOLUS \\ VULGARIS (L.)TO APHIS CRACCIVORA AND TETRANYCUS URTICAE PESTS INFESTATION, WITH REFERENCE TO THEIR NATURAL ENIMIES IN FAYOUM GOVERNORATE
}

\author{
ABD EL-WARETH, H.M. \\ Plant Protection Research Institute, A.R.C., Dokki, Giza, Egypt
}

ABSTRACT

The present investigation was carried out at El-Kasmia village, Etsa district, El-Fayoum Governorate during two growing season 2009 and 2010 to study susceptibility of four bean varieties, Branco, Narina, Giza 4 and Nbrasca to Aphis craccivora Koch and Tetranycus urticae Koch infestation with reference to their natural enemies ; Coccinella undecimpunctata and Chrysoperla carnea .

The obtained results indicated that Branco and Narina varieties more susceptible to $A$. craccivora which recorded $(11.5 \&$ 4.7) and $10.4 \& 4.0$ ) idividuals/20 leaves during the two growing seasons 2009 and 2010, respectively. On the other hand the less variety was Nbrasca which recorded numbers of A. craccivora 6.8 and 2.3 idividuals/20 leaves at 2009 and 2010 seasons respectively.

The results show that Giza 4 and Nbrasca varieties were more susceptible to mite infestation $T$. urticae which recorded mean numbers (171.6 and 140.4) ; (128.5 and 119.2) idividuals/20 leaves respectively; than Branco varieties which recorded (125.3 and 112.2) during the two seasons. On the other hand Narina variety was the last degree by mean 108.5 and 106.2 idividuals/20 leaves at the same trend.

Two peaks of $C$. undecimpunctata during two seasons in April and May which recorded 7.25 and 9.0 individuals/20 leaves during 2009 and 9.5 and 10.25 individuals/20 leaves during 2010. On contract $C$. carnea was low during two seasons which recorded, 4.75 and 5.0 individuals/20 leaves at May of two seasons.

Key words: Susceptibility, bean, varieties, Branco, Narina, Giza 4, Nbrasca ,Aphis craccivora, Tetranycus urticae, infestation, natural enemies, Coccinella undecimpunctata and Chrysoperla carnea.

\section{INTRODUCTION}

The common bean, Phaseolus vulgaris L. is considered one of the most important leguminous vegetable crop in many parts of the world as it contains a complete protein compared with the other vegetables .In Egypt, this crop has been subjected to attack by several pests and affect the quality and quantity of green pods and dry seeds production (Abdel-karim 2010 and Magouz et al., 2011).

Aphids, thrips, whitefly and leafminers are usually infested bean plant and cause losses at about $50 \%$ of this crop by feeding on the plant in addition to plant viruses transmission (Omar and Faris 2000; Helaly et al.,1983, Wahba et al .,1986 ; Metwally,1989 and Metwally and Mahgoub 1991 and Pena Rojas et al.,1992)

Also, phytophagous mites cause extensive damage to vegetable crops ,especially Tetranychus urticae L. widely spread and considered the main pest of vegetables, causing great losses in the yield, the effect of which is reduce

Fayoum J. Agric. Res. \& Dev., Vol. 27, No.1, January, 2013 
photosynthesis, transpiration leaf chlorophyll content ; leaf nitrogen, and increase transpiration (Golam,2002).

In general, the chemical control of these pests creates several problems i.e., environmental pollution, destruction of beneficial insects and pest resistance to many pesticides (John et al., 1986). Therefore, it is necessary to select the tolerant or resistant varieties as one of the simplest and useful tactics in the integrated pest management programs (Dent, 1991). However, plant resistance to insects is generally derived from certain biochemical and / or the metabolism of insects influencing the relative degrees of damage caused by these insects (Metcalf and Luckmann, 1975) .

The present work carried out to study the relative susceptibility of some common bean varieties to $A$. craccivora and $T$. urticae infestation with reference to their natural enemies in Fayoum Governorate .

\section{MATERIAL AND METHODS}

Experiments were carried out in El- Kasmia village, Etsa District, Fayoum Governorate, during 2009 and 2010 seasons. Four varieties involved in this study were Branco, Narina, Giza 4 and Nbrasca.The expermintal area of about $1 / 4$ feddan were divided into 36 plots, each of $24 \mathrm{~m}^{2}$ (6 m length X $4 \mathrm{~m}$ width). The tested varieties were swon in first February during two successive seasons respectively in a complete randomized blok design with three replicates for each. The regular agricultural practices were followed without any insecticidal treatments throughout the growing season of bean. Weekly samples of 20 bean compound leaves was collected at random from each plot till the end of growing seasons. The collected leaves were picked randomly, kept in paper bags and transferred to the laboratory to count individuals of cowpea aphid, spider mite, $C$. undecimpunctata and $C$. carnea by the aid of stereomicroscope.

Classification of the susceptibility degree of each bean cultivar infestation was determined according to the general mean of number ( $\mathrm{x}$ ) of each pest and the standard deviation (SD) as reported by Chiang and Talekar(1980). The variety that had mean numbers of aphids and spider mite less than X-2SD were considered to be highly resistant (HR); between X-1SD to $\mathrm{X}-2 \mathrm{SD}$ were moderately resistant (MR); between $\mathrm{X}$ and $\mathrm{X}-1 \mathrm{SD}$ were low resistant (LR); between $X$ and $X+2 S D$ were susceptible(S) and more than $\mathrm{X}+2 \mathrm{SD}$ were highly susceptible(HS).

The obtained data were statistically analyzed using F-test and the mean numbers of the two pests were compared according to Duncan's multiple rang test (Duncan, 1955).

\section{RESULTS AND DISCATIONS}

Data presented in (Table,1) indicated that the variety of bean, Nbrasca less susceptible to $A$. craccivora during two growing seasons. The mean numbers of $A$. craccivora were 6.8 and 2.3 individuals/20 leaves.

While, Branco variety was high susceptible to A. craccivora. The mean numbers were 11.5 and 4.7 individuals/20 leaves during 2009 and 2010, respectively.

During 2009 season data in (Table,1) revealed that first peak of infestation with A. craccivora was recorded in March, 10, 17 for Branco and Narina being 25.7 and 20.5 individuals/20 leaves for two varieties, respectively. The second peak for the same varieties were recorded in April

Fayoum J. Agric. Res. \& Dev., Vol. 27, No.1, January, 2013 
SUSCEPTIBILITY OF SOME BEAN VARIETIES; PHASEOLUS VULGARIS (L.)... 15 21, 28 for Narina and Branco being 22.6 and 23.7 individuals/20 leaves, respectively.

As shown in table (1) Branco and Narina varieties were more susceptible to infestation with aphids. The numbers of aphids were ranged between 3.5 to 23.7 individuals/20 leaves during the period between February and first June for Branco cv., while it ranged between 5.0 and 22.6 individuals/20 leaves for Narina cv.in the same period.

On the other hand, the mean numbers of aphid ranged between 1.7 to 22.1 individuals/20 leaves and 0.0 to 22.9 individuals/10 leaves for the two varieties, ie., Giza 4 and Nbrasca, respectively.

Statistical analysis of the data showed highly significant differences $(\mathrm{P}<0.01)$ between the four varieties as shown in (Table 1).

During 2010 growing season, data in (Table1) indicated that the mean numbers of aphid insects in the hall season were very low as compared with 2009 season in the four varieties.

The peak was recorded in March,17 for Giza 4 and Nbrasca variety being 6.7 and 4.6 individuals/20 leaves. While, it was recorded in March,24 for Branco and Narina varieties being 10.0 and 7.5 individuals/20 leaves.

The lowest infestations with aphid insects on the four varieties were recorded in June in the two growing seasons as shown in (Table 1).

Generally, data in (Table,1) revealed that variety of Branco and Narina were more sensitive to infestation with aphid than Giza 4 and Nbrasca cv. during two successive seasons.

Theses results agreement with the finding of Wahba et al.,(1986) indicated that some bean cultivars were susceptible to A. craccivora infestation, while others showed some tolerance. Processor cv. was more tolerant to aphid infestation with mean numbers 0.95 and 1.80 aphids/leaf, respectively, while Catue cv. was the highest susceptible with mean number 7.60 and 10.30 aphids/leaf, respectively, during summer periods of 1983 and 1984. The cultivars can be arranged in a descending order as follows: Slankette, Giza 6, Giza 3, Varandonon, Giza 4, and Rometto. BecquerHernandes and Ferrandiz-Puga (1981) found that the population dynamics of aphids (A. craccivora) on beans (Phaseolus vulgaris) were generally low throughout the year, the largest numbers being recorded in Novamber. AbdelKarim (2010), who found that there was no significant differences between Branco and Paulista (2.64 and 1.36 individuals/20leaves) infected by aphids during summer plantation.

Data presented in (Table, 2) indicated that the variety of bean, Narina was less susceptible to $T$. urticae during two growing seasons. The mean numbers of T. urticae were 108.5 and 106.2 individuals/20 leaves in 2009 and 2010, respectively, while Giza 4 variety was high susceptible to T. urticae in two seasons. The mean numbers were 171.6 and 128.5 individuals/20 leaves, at the same trend.

During 2009 season data in (Table, 2) revealed that the first peak of infestation with T. urticae was recorded in March, 17 for Branco and Narina being 93.0 and 125.5 individuals/20 leaves for two varieties, respectively. The second peak for the same varieties were recorded in April, 28 (391.4 and 312.6) individuals/20 leaves for Branco and Narina, respectively.

Fayoum J. Agric. Res. \& Dev., Vol. 27, No.1, January, 2013 
ABD EL-WARETH, H.M.

Table( 1):Weekly mean numbers of cowpea aphid, Aphis craccivora Koch on four varieties / 20 leaves for each cultivar under field conditions in Fayoum Governorate during 2009/2010 seasons.

\begin{tabular}{|c|c|c|c|c|c|c|c|c|}
\hline \multirow{2}{*}{$\begin{array}{c}\text { Sampling } \\
\text { dates }\end{array}$} & \multicolumn{4}{|c|}{ First season } & \multicolumn{4}{|c|}{ Second season } \\
\hline & Branco & Narina & Giza 4 & Nbrasca & Branco & Narina & Giza 4 & Nbrasca \\
\hline Feb., 17 & 3.5 & 5 & 1.7 & 0 & 5.5 & 2.7 & 0.9 & 0.4 \\
\hline 24 & 6.8 & 7.7 & 2.9 & 0 & 3.1 & 2.8 & 1.7 & 1.5 \\
\hline March, 3 & 19.9 & 11 & 3.8 & 1.1 & 1.7 & 3.7 & 2.8 & 2.6 \\
\hline 10 & 25.7 & 13.7 & 5.9 & 3.1 & 6.3 & 5.4 & 3.4 & 3.9 \\
\hline 17 & 18.4 & 20.5 & 7.3 & 7.7 & 8.4 & 6.4 & 6.7 & 4.6 \\
\hline 24 & 11.2 & 15.4 & 10.4 & 9.6 & 10 & 7.5 & 4.5 & 2.1 \\
\hline 31 & 9.4 & 10.1 & 22.1 & 6.4 & 6.6 & 3.9 & 3.2 & 1 \\
\hline April, 7 & 5.5 & 9.5 & 15.4 & 3.7 & 4.8 & 9.7 & 2.5 & 0.7 \\
\hline 14 & 10 & 18.2 & 9.3 & 2.5 & 3.2 & 4.9 & 1.9 & 1.3 \\
\hline 21 & 15.3 & 22.6 & 5.6 & 6.6 & 2.4 & 3.2 & 3.2 & 2.1 \\
\hline 28 & 23.7 & 10.7 & 7.1 & 9.6 & 2.1 & 3 & 6.7 & 3.4 \\
\hline May, 5 & 11.4 & 5.6 & 10.3 & 14.7 & 4.6 & 5.1 & 7.2 & 8.3 \\
\hline 12 & 9.8 & 7.4 & 12.7 & 22.9 & 8.2 & 2.7 & 4.3 & 2.9 \\
\hline 19 & 7.7 & 5.1 & 19.5 & 11.8 & 3.7 & 1.9 & 2.6 & 0.9 \\
\hline 26 & 3.5 & 3.3 & 9 & 7.9 & 3 & 1 & 1.2 & 0.4 \\
\hline June, 2 & 1.4 & 1 & 2.5 & 1.2 & 1.2 & 0.5 & 0.8 & 0 \\
\hline Total & 183.2 & 166.8 & 145.5 & 108.8 & 74.8 & 64.4 & 53.6 & 36.1 \\
\hline Mean & $11.5^{a}$ & $10.4^{b}$ & $9.1^{\mathrm{c}}$ & $6.8^{\mathrm{d}}$ & $4.7^{a}$ & $4.0^{a}$ & $3.4^{\mathrm{a}}$ & $2.3^{a}$ \\
\hline
\end{tabular}

Duncan's Multiple Rang Test $\mathbf{P}<0.01$

\begin{tabular}{|c|c|c|c|c|c|c|c|c|}
\hline \multirow{2}{*}{$\begin{array}{c}\text { Sampling } \\
\text { dates }\end{array}$} & \multicolumn{4}{|c|}{ First season } & \multicolumn{4}{|c|}{ Second season } \\
\hline & Branco & Narina & Giza 4 & Nbrasca & Branco & Narina & Giza 4 & Nbrasca \\
\hline Feb.,17 & 10 & 13.2 & 25.6 & 15.3 & 15.4 & 7.7 & 14.5 & 3.3 \\
\hline 24 & 21.2 & 40.3 & 47.9 & 26.4 & 61.2 & 24.5 & 33.3 & 15.4 \\
\hline March,3 & 60.3 & 75.1 & 88.4 & 78.5 & 50.1 & 42.1 & 57.4 & 27.8 \\
\hline 10 & 81.5 & 108.5 & 105.1 & 183.5 & 83.3 & 65.3 & 52.1 & 44.5 \\
\hline 17 & 93 & 125.5 & 144.5 & 77.6 & 34.9 & 71.7 & 50 & 76.8 \\
\hline 24 & 88.5 & 65.5 & 211.4 & 91.6 & 121.7 & 37.6 & 118.1 & 105.7 \\
\hline 31 & 108.5 & 105.7 & 134.1 & 183.5 & 165.6 & 111.5 & 212.5 & 142.1 \\
\hline April,7 & 190.2 & 299.5 & 196.7 & 265.2 & 248.6 & 174.4 & 232.5 & 184.2 \\
\hline 14 & 213.3 & 120.8 & 278.6 & 294.5 & 358.2 & 216.6 & 265.7 & 339.9 \\
\hline 21 & 365.5 & 164.5 & 399.2 & 319.5 & 217.4 & 297.8 & 320.2 & 280.6 \\
\hline 28 & 391.4 & 312.6 & 485.1 & 266 & 183.4 & 256.4 & 167.7 & 210.4 \\
\hline May,5 & 185.5 & 143.2 & 320.3 & 175.2 & 100.6 & 183.4 & 225.4 & 227.2 \\
\hline 12 & 93.1 & 85.9 & 135 & 129 & 78.1 & 100.9 & 147.3 & 109.1 \\
\hline 19 & 66.3 & 52.4 & 95.8 & 91.6 & 45.6 & 75.1 & 80.2 & 80.4 \\
\hline 26 & 25.6 & 20.5 & 61.7 & 38.5 & 22.3 & 22.5 & 59.3 & 46.7 \\
\hline June,2 & 10.4 & 3.4 & 15.6 & 11.2 & 8.8 & 11.2 & 20.4 & 12.5 \\
\hline Total & 2004.3 & 1736.6 & 2745 & 2247.1 & 1795.2 & 1698.7 & 2056.6 & 1906.6 \\
\hline Mean & $125.3^{b c}$ & $108.5^{c}$ & $171.6^{a}$ & $140.4^{b}$ & $112.2^{b c}$ & $106.2^{\mathrm{c}}$ & $128.5^{a}$ & $119.2^{\text {ab }}$ \\
\hline
\end{tabular}

Duncan's Multiple Rang Test $\mathbf{P}<0.01$

Fayoum J. Agric. Res. \& Dev., Vol. 27, No.1, January, 2013 
SUSCEPTIBILITY OF SOME BEAN VARIETIES; PHASEOLUS VULGARIS (L.)... 17

The second peak recorded in April,14 for Branco and Nbrasca being 358.2 and 339.9 individuals/20 leaves, respectively. While, it recorded in April, 21 for Narina and Giza 4 being 297.8 and 320.2 individuals/10 leaves, respectively.

The lowest infestations with $T$. urticae on the four varieties were recorded at June in the two growing seasons as shown in (Table, 2).

Generally, data in (Table, 2) revealed that the two varieties of Giza 4 and Nbrasca cv were highly susceptible than the two others varieties Branco and Narina were less sensitive to infestation with $T$. urticae during two successive seasons. The numbers of T. urticae were very high in April on all varieties.

Statistical analysis of the data showed highly significant differences $\mathrm{P}<0.01$ between the four varieties as shown in (Table, 2$)$.

These results are in agreement with the finding of, Abdel-Karim (2010), found that the Branco cultivar more susceptible to T. urticae infestation than Paulista cultivar. Also, the infestation was intensively in this season 2006 on the contrary to the infestation in summer season. Wahba et al., (1986) reported that the mean numbers of $T$. urticae of different bean varieties did not show any significant differences in summer and fall plantation of both years. The average numbers ranged between 1.12 on Giza $4 \mathrm{cv}$. and 4.08 on Giza 5 cv. But agreement with the finding of, Magouz et al., (2011) recorded that the highest numbers during the third week of July in the first season but in the the second season the highest numbers recorded in the fourth week of July. Based on the mean numbers of the two study seasons, variety Polesta harbored significantly the highest population of T. urticae followed by French bean and the breeding line F1 hybrid, R1655 was the lowest infested.

From the above mentioned results in Tables $(1 \& 2)$ its may be due to the decreasing and increasing population of aphids and spider mites, depend on climatic factors and/ or the abundance of the natural enemies as mentioned by Kumar (1984) who reported that the certain environmental conditions influence fundamental physiological processes of the plant as well as the pest. Thus, a variety that exhibits resistance in one locality or environmental may susceptible in another. Also, Metcalf and Luckmann (1975) recorded that certain environmental conditions may later the physiology of the plant to the extent that it becomes unsuitable as a host for certain pest. Also, plant resistant to insects is generally derived from certain biochemical and /or the metabolism of insects influencing the relative degrees of damage caused by aphids, spider mites and whitefly.

In respect to the susceptibility degree (SD) to the two pests, results in (Table 3) revealed that, two groups of susceptibility of bean varieties regarding infestation with the two pests in this experimental according to Chiang and Talekar (1980), are as follows: Branco and Narina were susceptible (S) to cowpea aphid but low resistant (LR) to spider mite. While, Giza 4 and Nbrasca were low resistant (LR) to spider mite but susceptible (S) to cowpea aphid, as shown in (Table 3).

From the foregoing results in Tables ( 1 and 2), it could be concluded that the population of the spider mite was more abundant than cowpea aphid during the two seasons. Also, Branco and Narina appeared susceptible to cowpea aphid, but Giza 4 and Nbrasca were susceptible to spider mite. While, Giza 4 and Nbrasca appeared low infested by cowpea aphid, but Branco and Narina appeared low resistant, respectively during two seasons.

Fayoum J. Agric. Res. \& Dev., Vol. 27, No.1, January, 2013 
Table(3): Susceptibilty of bean varieties to infestation with cowpea aphid, Aphis craccivora Koch and spider mite, Tetranycus urticae Koch on four varieties under field conditions in Fayoum Governorate during two seasons.

\begin{tabular}{|c|c|c|c|c|}
\hline Varieties & Aphis craccivora & SD & Tetranycus urticae & SD \\
\hline Branco & 8.1 & $\mathbf{S}$ & 118.8 & LR \\
\hline Narina & 7.2 & $\mathbf{S}$ & 107.4 & LR \\
\hline Giza 4 & 6.3 & LR & 150.1 & $\mathbf{S}$ \\
\hline Nbrasca & 4.6 & LR & 129.8 & $\mathbf{S}$ \\
\hline & $\begin{array}{c}X=6.6 \\
S D^{*}=1.80\end{array}$ & & $\begin{array}{c}X=126.5 \\
S D^{*}=44.6\end{array}$ & \\
\hline
\end{tabular}

SD: Susceptibility degree.

SD*: Standard deviation

Table( 4): Weekly mean numbers of predators / 20 leaves under field conditions in Fayoum Governorate during 2009/2010 seasons.

\begin{tabular}{|c|c|c|c|c|}
\hline \multirow{2}{*}{$\begin{array}{l}\text { Sampling } \\
\text { dates }\end{array}$} & \multicolumn{2}{|c|}{ First season } & \multicolumn{2}{|c|}{ Second season } \\
\hline & C. u. & C. $c$. & C. u. & C. $c$. \\
\hline Feb.,17 & 2.25 & 0 & 3.00 & 0 \\
\hline 24 & 2.50 & 0 & 3.00 & 0 \\
\hline March,3 & 3.00 & 0 & 4.00 & 0 \\
\hline 10 & 4.50 & 0 & 5.00 & 0 \\
\hline 17 & 5.25 & 0 & 5.50 & 0 \\
\hline 24 & 5.50 & 0 & 6.00 & 0 \\
\hline 31 & 6.00 & 0 & 3.00 & 0 \\
\hline April,7 & 4.00 & 1.25 & 3.25 & 1.00 \\
\hline 14 & 4.25 & 1.25 & 3.50 & 1.25 \\
\hline 21 & 4.50 & 1.00 & 6.25 & 0.00 \\
\hline 28 & 7.25 & 1.50 & 9.50 & 1.00 \\
\hline May,5 & 6.00 & 2.50 & 7.25 & 3.00 \\
\hline 12 & 6.50 & 3.50 & 7.50 & 3.25 \\
\hline 19 & 7.00 & 3.50 & 7.25 & 4.00 \\
\hline 26 & 9.00 & 4.75 & 10.25 & 5.00 \\
\hline June,2 & 5.00 & 1.50 & 7.00 & 2.00 \\
\hline 9 & 4.75 & 1.25 & 6.50 & 1.50 \\
\hline 16 & 4.00 & 1.00 & 4.25 & 1.25 \\
\hline 23 & 2.25 & 0.00 & 2.50 & 0.25 \\
\hline Total & 93.50 & 24.50 & 104.50 & 23.5 \\
\hline Mean & 4.96 & 1.29 & 5.50 & 1.24 \\
\hline
\end{tabular}

C. u.: Coccinella undecimpunctata

C. c.: Chrysoperla carnea

In (Table, 4), the data revealed that means numbers of $C$. undecimpunctata during two seasons 4.96 and 5.50 as compared with 1.29 and 1.24 for $C$. carnea individuals/20 leaves, respectively.

Fayoum J. Agric. Res. \& Dev., Vol. 27, No.1, January, 2013 
SUSCEPTIBILITY OF SOME BEAN VARIETIES; PHASEOLUS VULGARIS (L.)... 19

Concerning (Table, 4) the presented data show that the numbers of $C$. carnea during two seasons were 0.0 till the end of March as compared with the numbers of $C$. undecimpunctata which recorded means ranged between (2-6) and (3-6) individuals/20 leaves in the two seasons 2009 and 2010, respectively.

Data in the same table indicated that there were two peaks of $C$. undecimpunctata during first season i.e., 7.25 and 9.0 individuals/20 leaves at April,28 and May,26, respectively.

On the other hand there were also two peaks in the numbers of $C$. undecimpunctata at 2010 season being 9.5 and 10.25 individuals/20 leaves in the same dates, respectively.

In general, the data presented in (Table, 4) show that the numbers of $C$. carnea were low during two seasons except one peak in the two seasons in May,26 (4.75 and 5.00) individuals/20 leaves.

Finally, the highly numbers of $C$. undecimpunctata and $C$. carnea were recorded at the end of May during two seasons.

\section{REFERENCES}

Abdel-Karim, H.S. (2010): Studies on some Arthropods inhabiting bean plants (Phaseolus vulgaris L.) in Fayoum Governorate. M.Sc. Thesis, Fac. of Agric., Al-Fayoum Univ., 113pp.

Becquer-Hernandes, A. and R. Ferrandiz-Puga (1981): Population dynamic of aphid population in fields of beans (Phaseolus vulgaris L.). Ciencias de la Agricultura, 8:23-28.

Chiang, H.S. and N.S. Talekar(1980): Identification of sources of resistance to the bean fly and two agromized flies in soybean and mungbean. J. Econ. Entomol. 73(2):197-199.

Dent, D. (1991): Insect pest management . C.A.B. International Wallingford UK. 604.pp.

Duncan, D.B. (1955): Multiple rang and multiple F tests Biometrics. 11:142.

Glen, R. (1954): Factors that affect insect abundance. J. Econ. Ent., 47: 398405.

Golam, A. (2002): Management of spider mite;(Tetranychus urticae) in vegetable crops in Caernarvon. Published by the Department of Agriculture Western Australia Locked Bag. No. 4, Bentley Delivery Center, W. A. G., 983.

Gomez, K.A. and A.A. Gomez (1984). Statistical Procedures for Agricultural Research. Second Edition, John Wiley and Sons, New York, pp. 139153.

Helaly, M.M., A.E. Ibrhim and M.R.A. Saleh (1983): Fluctuation of population densities of Empoasca sp., Aphis craccivora Koch and Tetranycus arabicus Attiah attacking Cowpea plants Zagazig, Egypt. Bull. Ent., Soc. Egypt.

John, W.N. JR., S. Maria and M. Katherine (1986): Toxicity of clorfentezine against the two spotted spider mites (Acari: Tetranychidae) . J. Econ. Entomol., 79(2): 479-483.

Kumar, R. (1984): Insect pest control with special reference to African agriculture. Edward Arnold, London. 298pp.

Magouz, R.I.E., S.A.A. Kassem and Jehan B. EL- Naggar (2011): Evaluation of certion kidney bean, Phaseolus vulgaris L. verities for their infestation with Tetranycus cucurbitacearum (Sayed) and Bemisia

Fayoum J. Agric. Res. \& Dev., Vol. 27, No.1, January, 2013 
ABD EL-WARETH, H.M.

tabaci (Genn.) under field conditions of Kafer EL-Sheihk. Egypt. J. Agric. Res., (4), 1287-1294.

Metcalf, R.L. and W.H. Luckmann (1975): Introduction to insect pest management. John Wiley \& Sons, Inc. New York. 587pp.

Metwally, S.A.G. (1989): Ecological studies on some insect pests infesting certain legume cropsin Qualubia goernorate. Ph.D. Thesis, Fac. Agric., Cairo Univ.

Metwally, S.A.G. and M.M.A. Mahgoub (1991): Susceptibility of Cowpea varieties to Aphis craccivora Koch with special reference to Enzymes activates and reducing Sugar. Fourth Arab Congress of Plant Protection Cairo, 1-5 Dec.: 153-157.

Omar, B.A. and F.S. Faris (2000): Bio-residual activity of different insecticides on the leaf miners and yield components of snap bean( Phaseolus vulgaris L.) Egyptian J. Agric. Res. 78(4), 1485-1497.

Pena Rojao, E.A., A. Pantoja and J.S. Beaver (1992): Determination of the four genotype of bean Phaseolus vulgaris L.and its effect on the insect Bemisia tabaci (Genn.) Reviota Colombiana de Etomologia, 18 (2): 41 ( C.F. Rev. Agric Ent.) 82 (7): 9846.

Wahba, M.L., S.A. Doss, F.S.Faris and M.K. Nakhla (1986): Evaluation of some Phaseolus vulgaris L. cultivars to infestation with aphids and mites. Agric. Res. Rev., 64(1): 163-170.

$$
\begin{aligned}
& \text { قابلية بعض أصناف الفاصوليا للإصابة بمن اللوبيا والعنكبوت الأحمر مع الإشارة } \\
& \text { إلي أعدائها الحيوية بمحافظة الفيوم الفيا والفكبوت } \\
& \text { حمادة محمد عبد الحميد عبد الوارث } \\
& \text { معهد بحوث وقاية النباتات ـ الاقي ــ الجيزة- مصر الور }
\end{aligned}
$$

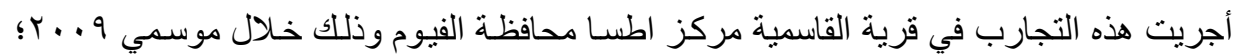

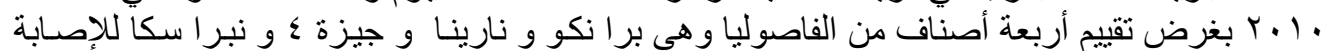

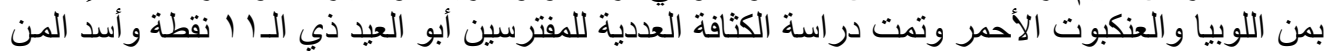

$$
\begin{aligned}
& \text { وذللك خلال موسمي الدر اسة. }
\end{aligned}
$$

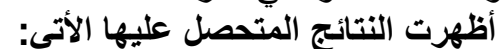

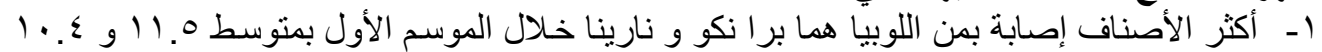

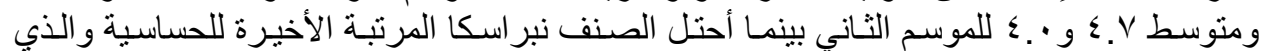

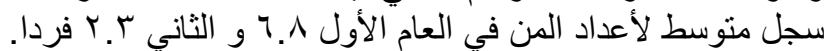

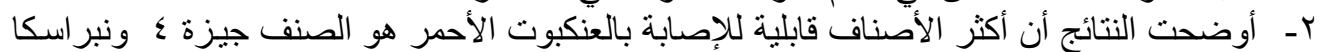

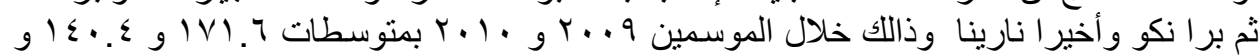

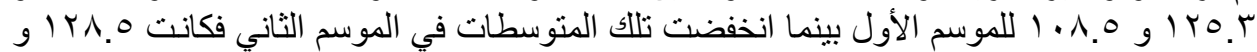

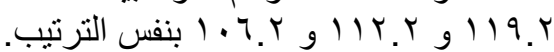

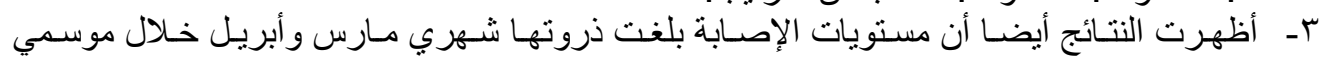

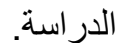

$$
\begin{aligned}
& \text { ع - ـ وأوضحت النتائج أن أكبر كثافة لحشرة أبو العيد خلال موسمي الدراسة كانت في شهر أبريل ومـايو }
\end{aligned}
$$

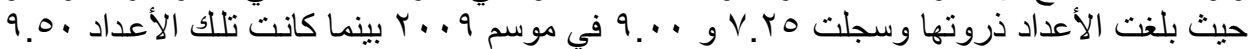

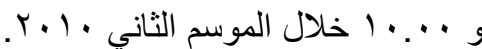

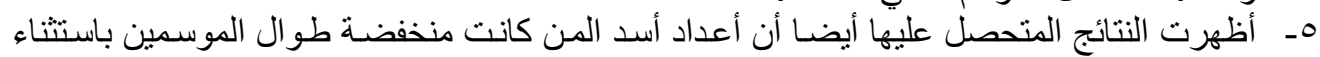

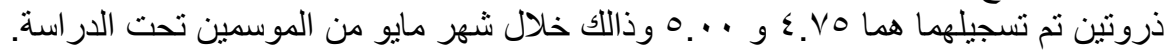

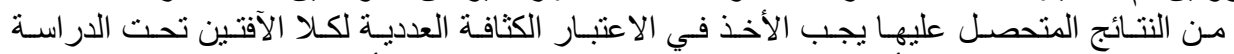

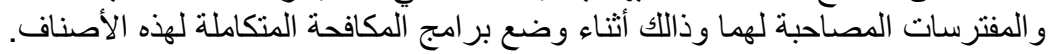

Fayoum J. Agric. Res. \& Dev., Vol. 27, No.1, January, 2013 